\title{
LIVE AND FORMULATED DIET EVALUATION THROUGH INITIAL GROWTH AND SURVIVAL OF JUNDIÁ LARVAE, Rhamdia quelen
}

\author{
Paulo César Falanghe Carneiro ${ }^{*}$; Jorge Daniel Mikos ${ }^{1}$; Marianne Schorer ${ }^{1}$; Paulo Roberto \\ Campagnoli Oliveira Filho'; Fabiano Bendhack ${ }^{2}$ \\ ${ }^{1}$ PUCPR - CCAA Zootecnia, C.P. 129 - 83010-500 - São José dos Pinhais, PR - Brasil. \\ ${ }^{2}$ CAUNESP - Via Acesso Paulo Donato Castelane, s/n - 14884-900 - Jaboticabal, SP - Brasil. \\ Corresponding author <carneiro@rla01.pucpr.br>
}

ABSTRACT: Live diet (LD) dependence and the lack of suitable formulated diets (FD) are major constraints for the expansion of larviculture of many fish species. The low digestibility and nutritional quality of FD are factors that might explain their failure as a stand-alone starter food. To determine whether FD in combination with LD (zooplankton) may efficiently increase larval growth and survival of jundiá (Rhamdia quelen), when compared to fish fed by either types of diet alone, jundiá larvae $(5.57 \mathrm{~mm} ; 1.41 \mathrm{mg})$ were initially stocked into 12 10-L aquaria (100 larvae per aquarium). Replicate groups $(n=4)$ were fed ad libitum one of the three diets for 20 (when fed FD) or 48 days (when fed LD or the combined diets). Larvae fed FD alone presented significantly lower survival and growth rates as compared to larvae fed LD or a combination of both (co-fed). In addition, co-fed larvae grew better $(170 \mathrm{mg})$ in relation to those fed solely with LD (110 $\mathrm{mg}$ ). Such better performance of combined feeding indicates that most of the required nutrients are in balance when both diet sources are included. More can be learned about fish larvae nutrition by further testing the effect of feeding combined diets, which include zooplankton, than only testing new ingredients or protein sources commonly used in the elaboration of juvenile or adult fish feeds.

Key words: feed, zooplankton, nutrition, silver catfish

\section{ALIMENTO VIVO E FORMULADO, CRESCIMENTO INICIAL E SOBREVIVÊNCIA DE PÓS-LARVAS DE JUNDIÁ, Rhamdia quelen}

\begin{abstract}
RESUMO: A larvicultura da maioria das espécies de peixes enfrenta o desafio da dependência do alimento vivo $(\mathrm{AL})$ e da falta de dietas formuladas $(\mathrm{DF})$ que atendam plenamente às necessidades das larvas. $\mathrm{A}$ baixa digestibilidade e a qualidade nutricional das DFs são alguns dos fatores que explicam o insucesso quando as larvas recebem apenas FD. Para avaliar o efeito da combinação da DF com o AL no crescimento e na sobrevivência de larvas de jundiá (Rhamdia quelen), comparando com o uso separado da DF ou do AL, larvas recém eclodidas $(5,57 \mathrm{~mm} ; 1,41 \mathrm{mg})$ foram estocadas inicialmente em 12 aquários de $10 \mathrm{~L}$ (100 larvas por aquário). Quatro réplicas foram alimentadas ad libitum com uma das três dietas por 20 (para DF) ou 48 dias (para AL ou a combinação DF + AL). As larvas alimentadas com apenas DF apresentaram crescimento e sobrevivência reduzidos quando comparadas àquelas alimentadas com AL ou a combinação DF + AL. Adicionalmente, as larvas do tratamento DF + AL apresentaram maior crescimento em peso (170 mg) que aquelas alimentadas apenas com AL $(110 \mathrm{mg})$. O melhor desempenho das larvas alimentadas com $\mathrm{DF}+\mathrm{AL}$ mostra que a maioria dos nutrientes exigidos pelas larvas é fornecida mais adequadamente quando ambas as dietas são fornecidas juntamente. Contudo, trabalhos sobre nutrição larval poderão contribuir ainda mais sobre a elucidação deste tema quando feitas comparações com o uso combinado de DF + AL, do que apenas testando isoladamente novos ingredientes e fontes protéicas normalmente utilizadas na elaboração de dietas para juvenis e adultos.

Palavras-chave: ração, zooplâncton, nutrição, bagre cinza
\end{abstract}

\section{INTRODUCTION}

Nutritionally adequate starter diets are essential for the success of larviculture of many fish species, since the critical period of aquaculture production has been identified as the start of the exogenous feeding (Conceição et al., 1998; García-Ortega et al., 2001). Once the yolk sac reserves are depleted, the acquisition of nutrients by fish depends on the ingestion of zooplankton organisms found in their natural habitat. Because in intensive aquaculture systems the cultivation and maintenance of live food organisms is costly, labor intensive, unpredictable and in some cases could lead to the production of live food with suboptimal nutritional quality, 
efforts are being made for their partial or total replacement by formulated diets (Cahu \& Zambonino-Infante, 2001).

Several formulated diets for fish larvae have been tested with relative success. However, the results on growth and survival achieved with these diets were inferior to the use of live food, possibly because of the composition, palatability, physical characteristics (Person Le Ruyet et al., 1993) or to an inability of properly digesting the feed (Kolkovsky, 2001). Higher growth rates can be obtained by combined feeding of formulated diets and live food supplementation (e.g. Artemia nauplii) or cofeeding (Luchini \& Salas, 1984; Canavate \& FernandesDiaz, 1999). This all has been shown to enhance larval performance beyond that achieved by feeding either types of diets alone (Holt, 1993; Cahu \& Zambonino-Infante, 2001), and to permit weaning in a shorter time (Person Le Ruyet et al., 1993).

The importance of using combined live and formulated diets lies mainly in supplying a more suitable and well balanced diet to fish larvae in a digestive form. A number of other important aspects related to nutrition, species, fish biology, and husbandry conditions, which determine the success of using combined feeding, are not yet fully understood. For instance, there appear to be specific periods during development when fish larvae will feed on, and metabolize formulated diets, and that can be accounted for a behavioral and a physiological capacity (Cahu \& Zambonino-Infante, 2001; Petkam \& Moodie, 2001). Moreover, some fish species larvae apparently are better adapted to the utilization of nutrients from formulated diets than others.

Jundiá (Rhamdia quelen) is an important freshwater catfish commonly found in many Brazilian rivers and in other regions of Latin America. Several studies carried out on this species have pointed out jundiá as a promising new species for aquaculture in Brazil (Piaia et al., 1999; Chippari-Gomes et al., 2000; Gomes et al., 2000; Uliana et al., 2001; Carneiro et al., 2002). One good reason is that jundiá larvae seem to accept inert dry diet from the very beginning of exogenous feeding. Such behavior is crucial during husbandry procedures for fingerling production. Nevertheless, other important aspects need to be considered during the first feeding of fish larvae (Kolkovski, 2001). Therefore, the objective of this study was to determine whether formulated diet (FD) in combination with live diet (LD) may efficiently increase larval growth and survival of jundiá, when compared to fish fed by either types of diets alone.

\section{MATERIAL AND METHODS}

\section{Fish larvae source and trial design}

Jundiá larvae were obtained from confined brood stock (body weight $400-600$ g) in São José dos Pinhais,
SP, Brazil $\left(25^{\circ} 34^{\prime}\right.$ S; $49^{\circ} 11^{\prime}$ W; 930 m). Pituitary extract was used in an overall breeding procedure similar to that commonly used for many fish species (Carneiro et al., 2002). Hatching occurred within $24 \mathrm{~h}$ of fertilization at $22^{\circ} \mathrm{C}$, and three days later larvae from conical incubators were pooled, removed from incubators and allocated to 12 plastic aquaria. One hundred larvae $(1.41 \pm 0.31 \mathrm{~g}$ and $5.57 \pm 0.65 \mathrm{~cm}$ mean \pm standard deviation) were reared in each 10-L plastic aquarium under aeration. One day was allowed for recovery and dead larvae were replaced to maintain the density of 10 larvae per liter prior to the start of the experiment.

The experiment was carried out for 48 days in a 13:11 h light:dark photoperiod regime. Treatments were formulated diet (FD) and live diet (LD), alone or in combination (Co-fed). FD larvae were fed in excess four-six times a day; zooplankton was provided to LD and Cofed groups once a day with abundant and in similar quantity per aquarium throughout the experimental period. To enable better growth, rate number of larvae was reduced to ten per aquarium from day 20 to day 35 , and then reduced again to five until the end of the experimental period. Parcels receiving FD alone had high mortality and treatment was terminated on day 20 .

\section{Food sources}

FD consisted of powdered commercial feed used for fingerling production (crude protein $\geq 45 \%$, lipid $\geq$ $10 \%$, crude fiber $\leq 6 \%$, ash $\leq 14 \%$, calcium $\leq 2.5 \%$, phosphorus $\geq 1.0 \%$, and moisture $\leq 13 \%$ ). Zooplankton was captured on a daily basis ( $60 \mu \mathrm{m}$ mesh net) from a fertilized earthen pond and graded by nylon mesh sieves (100 to $1000 \mu \mathrm{m}$ ) before feeding, according to the larvae size.

\section{Samplings, growth and mortality}

Larvae were randomly sampled from each experimental aquarium $(n=4)$ on day 20,35 , and 48 , and preserved in $10 \%$ formalin solution. Total length and weight were measured with the aid of stereomicroscope and electronic scale, respectively. The condition factor $(\mathrm{K})$ was calculated as follow:

$$
K=\frac{W^{3}}{L} x 1000
$$

where $\mathrm{W}$ and $\mathrm{L}$ are weight $(\mathrm{mg})$ and total length $(\mathrm{mm})$, respectively.

Growth was reported as specific growth rate (SGR - \% change in body weight per day) and calculated from average body weights as follows:

$$
S G R\left(\% \quad \text { day }^{-1}\right)=\frac{100\left[\ln \left(W_{2}\right)-\ln \left(W_{1}\right)\right]}{\operatorname{period}(\text { days })}
$$

where $\mathrm{W}_{1}$ and $\mathrm{W}_{2}$ are the initial and final weights (mg), respectively. Dead fish were removed daily and cumula- 
tive mortality rate was recorded as the percentages of the total number of larvae stocked in each period between samplings.

\section{Water quality}

Aquaria were siphoned daily for waste removal; $10 \%$ of water volume was replaced. Water temperature, $\mathrm{pH}$ and dissolved oxygen (DO) were measured daily with digital meters. Water temperatures ranged from 25 to $28^{\circ} \mathrm{C}$, and $\mathrm{pH}$ from 7.4 and 8.3. DO levels were maintained $\geq 5.4 \mathrm{mg} \mathrm{L}^{-1}$ throughout the experimental period. Ammonia concentrations (mg L $\left.{ }^{-1}\right)$ were measured weekly using a Lammote ${ }^{\circledast}$ kit and the levels were kept under $1 \mathrm{mg} \mathrm{L}^{-1}$ during the trial period.

\section{Statistical analysis}

The trial was set up in a completely randomized design $(n=4)$. Effects of different treatments on total length, mean weight, condition factor and specific growth rate were tested by one-way analysis of variance. When differences were detected $(P=0.05)$, Tukey test $(P=0.05)$ was used to compare treatment means at day 20 . As there were only two treatments from day 20 on, mean values from samples taken on days 35 and 48 were compared by the Student T test $(P=0.05)$.

\section{RESULTS AND DISCUSSION}

Cannibalism was observed during all experimental period, mainly on the first days, in all treatments. Five days after starting the feeding trial, fish larvae fed only formulated diet (FD) were visually smaller than those fed live diet (LD) or a combination (Co-fed). Moreover, FDfed larvae were less active and remained dispersed on the bottom of the aquaria. Larvae fed solely zooplankton were swimming mainly near the lateral walls of the aquaria, at half depth. Co-fed larvae had an intermediate behavior, swimming either near the bottom or the walls. During the first days, live food seemed to be more attractable to the co-fed larvae than the formulated diet. Co-fed larvae presented more interest for FD at the end of the first week. Nevertheless, co-fed jundiá larvae seemed to wean from LD to FD gradually and spontaneously during the first days of life.

The effects of the dietary treatments on growth are reported in terms of total length, body weight and specific growth rate (SGR). FD-fed larvae had poor growth and very high mortality at day 20 . As a consequence, FD treatment was terminated at day 20. The LD and co-fed treatments were carried out until the end of the experimental period (day 48). Total length, body weight, condition factor (K), and (SGR) were significantly reduced $(P \leq 0.05)$ for FD-fed larvae (Figures 1, 2, 3, and 4).

Co-fed larvae presented higher total length $(P \leq 0.05)$ than LD-fed larvae only at the end of the experimental period (Figure 1). In addition, Co-fed larvae

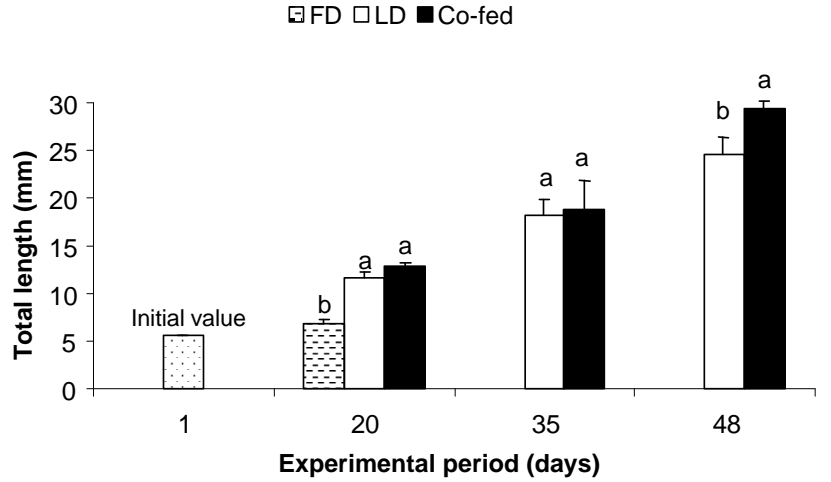

Figure 1 - Mean total length of jundiá (Rhamdia quelen) larvae fed formulated diet (FD), live diet (LD), and combination of FD and LD (Co-fed) for 48 days under laboratory conditions. Different letters indicate differences $(P \leq 0.05)$ among treatments at the same sampling time. Vertical bars represent the standard error of the mean.

घFD $\square$ LD $\square$ Co-fed

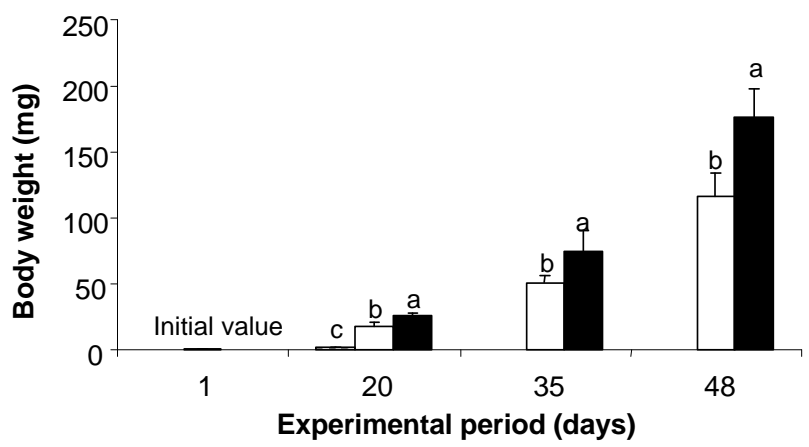

Figure 2 - Mean body weight of jundiá (Rhamdia quelen) larvae fed formulated diet (FD), live diet (LD), and combination of FD and LD (Co-fed) for 48 days under laboratory conditions. Different letters indicate differences $(P \leq 0.05)$ among treatments at the same sampling time. Vertical bars represent the standard error of the mean.

$$
\text { EFD } \square L D \square \text { Co-fed }
$$

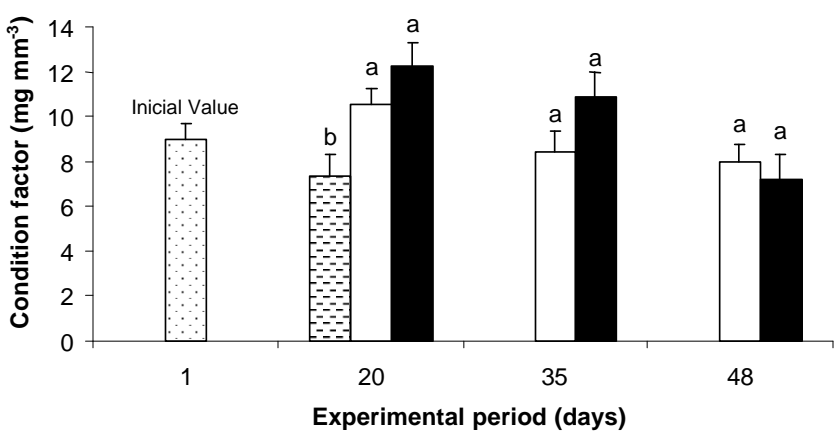

Figure 3 - Mean condition factor (K) of jundiá (Rhamdia quelen) larvae fed formulated diet (FD), live diet (LD), and combination of FD and LD (Co-fed) for 48 days under laboratory conditions. Different letters indicate differences $(P \leq 0.05)$ among treatments at the same sampling time. Vertical bars represent the standard error of the mean. 
had higher body weight $(P \leq 0.05)$ than the larvae fed only live food from day 20 forth. Noteworthily, LD-fed larvae presented higher growth and survival rates than FD-fed larvae (Figures 2 and 5). Condition factor and SGR had similar patterns for LD-fed and co-fed larvae during the whole experimental period, but presented higher values $(P \leq 0.05)$ than FD-fed larvae at day 20 (Figures 3 and 4 ).

Approximately $80 \%$ of the LD and co-fed larvae survived until the $42^{\text {nd }}$ day of the trial, whereas only $30 \%$ of FD-fed larvae survived during the first 20 days (Figure 5). The higher mortality and lower growth of FD fed larvae, as compared to the LD and co-fed treatments, allow to infer that FD-fed larvae were malnourished, although they were fed in excess. FD-fed larvae searched for food throughout the experimental period, but with lower activity when compared to the larvae from the other treatments. At day 40 all aquaria were infected with the ectoparasite Ichthyophthirius multifiliis during routine si-

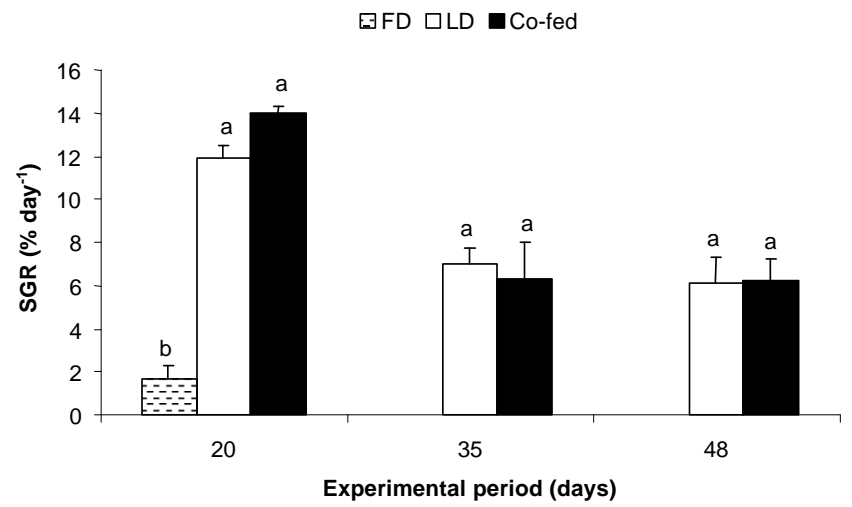

Figure 4 - Specific growth rate (SGR \%/day) of jundiá (Rhamdia quelen) larvae fed formulated diet (FD), live diet (LD), and combination of FD and LD (Co-fed) for 48 days under laboratory conditions. Different letters indicate differences $(P \leq 0.05)$ among treatments at the same sampling time. Vertical bars represent the standard error of the mean.

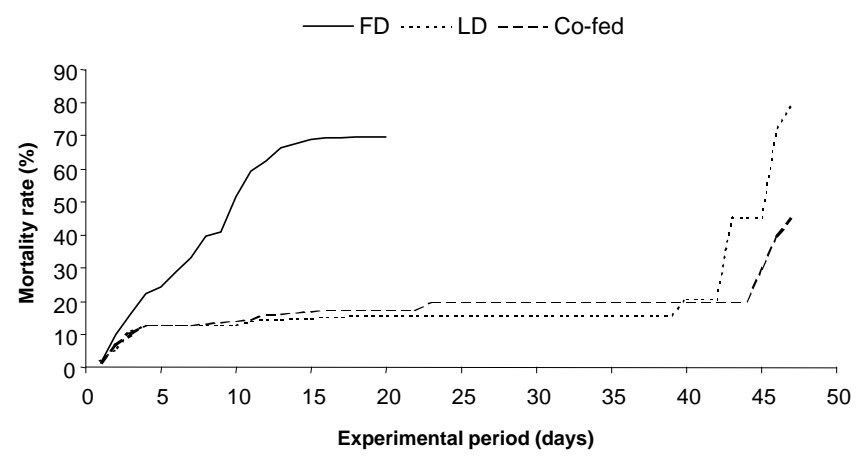

Figure 5 - Mortality rate (\%) of jundiá (Rhamdia quelen) larvae fed formulated diet (FD), live diet (LD), and combination of FD and LD (Co-fed) for 48 days under laboratory conditions. phoning, causing high fish mortality in all treatments. However, co-fed larvae seemed to endure longer and presented higher survival rate (Figure 5). Co-fed larvae seemed to be better nourished and well fit to overcome injuries, such as a parasitic infestation.

The production of fish larvae and fingerlings of most fish species relies largely on feeding strategies based on live food. Because live food organisms also have to be cultured, these strategies pose extra strain mainly on hatchery management, leading to increase fingerling production costs. Development of suitable formulated and/ or mix feeding larval diets have alleviated these problems, increasing the reliability and improving the cost-benefit of the fingerling production in fish hatcheries.

Several studies have been dedicated to develope feasible co-feeding strategies for fish larvae. Fermin \& Bolivar (1991) and Petkam \& Moddie (2001) observed that co-feeding practices resulted in better growth of walking catfish, Clarias macrocephalus, larvae. Jundiá larvae were observed eating formulated diet at an early stage of exogenous feeding. Walking catfish larvae fed live diet (Artemia) for the first 10 days, followed by formulated diet for the next 11 days, grew significantly better in length and body weight than larvae which received diet composed only of either Artemia or formulated diet. Moreover, Rosenlund et al. (1997) and Canavate \& Fernandez-Diaz (1999) observed that the application of a co-feeding strategy in some commercially important marine aquacultural species, such as sole (Solea senegalensis), seabass (Dicentrarchus labrax), gilthead seabream (Sparus aurata) and others, improved growth and survival rates. Even though formulated diet may be consumed inefficiently by jundiá at the start of exogenous feeding, it can be suitable and even more adequate than live diet in a later hatchery stage.

Formulation of compound, adequate diets for fish larvae at the early life stage is not easy to be achieved because the estimation of nutritional requirements of fish larvae cannot be carried out by traditional nutritional approaches. Moreover, live diets ingested by larvae contain exogenous substances such as gut neuropeptides, enzymes and nutritional growth factors that contribute to the digestion of prey, frequently omitted in formulated diets (Rosenlund et al., 1997). To date, when used alone from the onset of the exogenous feeding, commercially, formulated diets do not support the growth of larvae of most fish species.

Zooplankton, a group of organisms ordinarily present in aquaculture ponds, is an essential diet for fish larvae, supplying many nutrients (in the digestive form) required by the larvae. In the current study, jundiá larvae fed solely formulated diet presented poor growth and survival rates. As the fish larvae grow, energy requirement to capture such a prey increases and this could explain why jundiá larvae fed only live diet did not grow 
as efficiently as those fed a combination of live and formulated diets, especially during the second half of the larval stage.

Sucess on cultivation of jundiá larvae, like many other fish species, is markedly improved when live diet is provided (Rottmann et al., 1991). Feeding only formulated diet may result in physiological and/or morphological immaturity of the digestive system of fish larvae, and in the absence of proteolytic enzymes, supplied by live food in the digestive tract, or both (Ronnestad et al., 1999; Kolkovski, 2001). A deficiency in digestive enzymes in young larvae explains the lack of success in formulated diet feeding (Dabrowski \& Glogovski, 1977; Lauff \& Hofer, 1984). A potential role of the enzymes of prey organisms in larval digestion has often been argued, but without conclusive results. Zooplankton may be consumed by the larvae assist the digestion process by donating their digestive enzymes, either by autolysis or as zymogens, which activate the larval endogenous digestive enzymes (Kolkovski, 2001). There is no consensus on this subject, and proteases derived from live diet have been shown to make only a small contribution to enzymatic activity in some fish species (Cahu \& ZamboninoInfante, 2001). Feeding prey organisms for a short time before formulated diet is offered may increase digestive activity and increase the ability of larvae to digest formulated diets. Additionally, the superior growth of larvae fed live diet may result from increased food intake, nutrient digestibility, and assimilation of live diet, instead of higher nutritional value (Cahu \& Zambonino-Infante, 2001).

Combining formulated and live diet at an early developmental stage seems to improve growth and survival of jundiá larvae as compared to the single use of either formulated or live diets. This practice seems to improve and stabilize the nutritional condition of the larvae and pre-condition them to accept the formulated diet when live diet is withdrawn, resulting in a shorter weaning period. Consequently, the production of improved diets could also allow and sustain the low production cost of high quality fingerlings under laboratory conditions.

\section{REFERENCES}

CAHU, C.; ZAMBONINO-INFANTE, J. Substitution of live food by formulated diets in marine fish larvae. Aquaculture, v.200, p.161-180, 2001.

CANAVATE, J.P.; FERNANDEZ-DIAZ, C. Influence of co-feeding larvae with live and inert diets on weaning the sole, Solea senegalensis, onto commercial dry feeds. Aquaculture, v.174, p.255-263, 1999.
CARNEIRO, P.C.F.; BENDHACK, F.; MIKOS, J.D.; SCHORER, M.; OLIVEIRA FILHO, P.R.C. Jundiá: um grande peixe para a Região Sul. Panorama da Aqüicultura, v.12, p.41-46, 2002.

CHIPPARI-GOMES, A.R.; GOMES, L.C.; BALDISSEROTTO, B. Lethal temperatures for Rhamdia quelen larvae (Pimelodidae). Ciência Rural, v.30, p.1069-1071, 2000.

CONCEIÇÃO, L.E.C.; OZÓRIO, R.O.A.; SUURD, E.A.; VERRETH, J.A.J. Amino acid profiles and amino acid utilization in larval African catfish (Clarias gariepinus): effects of ontogeny and temperature. Fish Physiology and Biochemistry, v.19, p.43-57, 1998.

DABROWSKI, K.; GLOGOVSKI, J. Studies on the role of exogenous proteolytic enzymes in digestion processes in fish. Hydrogiologia, v.54, p.129-134, 1977.

FERMIN, A.C.; BOLÍVAR, M.E.C. Larval rearing of the Philippine freshwater catfish, Clarias macrocephalus (Gunther), fed live zooplankton and artificial diet: a preliminary study. Bamindgeh, v.43, p.87-94, 1991.

GARCÍA-ORTEGA, A.; HUISMAN, E.A.; SORGELOOS, P.; VERRETH, J. Evaluation of protein quality in microbound started diets made with decapsulated cysts of Artemia and fish meal for fish larvae. Journal of the World Aquaculture Society, v.32, p.317-329, 2001.

GOMES, L.C.; GOLOMBIESKI, J.I.; CHIPPARI-GOMES, A.R.; BALDISSEROTTO, B. Biologia do Jundiá Rhamdia quelen (Teleostei, Pimelodidae). Ciência Rural, v.30, p.179-185, 2000.

HOLT, G.J. Feeding larval red drum on microparticulate diets in a closed recirculating water system. Journal of World Aquaculture Society, v.24, p.225-230, 1993.

KOLKOVSKI, S. Digestive enzymes in fish larvae and juveniles implications and application to formulated diets. Aquaculture, v.200, p.181-201, 2001.

LAUFF, M.; HOFER, R. Proteolytic enzymes in fish development and the importance of dietary enzymes. Aquaculture, v.37, p.335-346, 1984.

LUCHINI, L.; SALAS, T.A. Preliminary data on larval survival of south american catfish, Rhamdia sapo. Aquaculture, v.42, p.175-177, 1984.

PERSON LE RUYET, J.; ALEXANDRE, J.C.; THÉBAUD, L.; MUGNIER, C. Marine fish larvae feeding: Formulated diets or live prey? Journal of World Aquaculture Society, v.24, p.211-224, 1993.

PETKAM, R.; MOODIE, G.E. Food particle size, feeding frequency, and the use of prepared food to culture larval walking catfish (Clarias macrocephalus). Aquaculture, v.194, p.349-362, 2001.

PIAIA, R.; TOWNSEND, C.R.; BALDISSEROTTO, B. Growth and survival of fingerlings of silver catfish exposed to different photoperiods. Aquaculture International v.7, p.201-205, 1999.

RONNESTAD, I.; THORSEN, A.; FINN, R.N. Fish larval nutrition: a review of recent advances in the roles of amino acids. Aquaculture, v.177, p.201-216, 1999.

ROSENLUND, G.; STOSS, J.; TALBOT, C. Co-feeding marine fish larvae with inert and live diets. Aquaculture, v.155, p.183-191, 1997.

ROTTMANN, R.W.; SHIREMAN, J.V.; LINCOLN, E.P. Comparison of three live foods and two diets for intensive culture of grass carp and bighead carp larvae. Aquaculture, v.96, p.269-280, 1991.

ULIANA, O.; SILVA, J.H.S.; NETO, J.R. Diferentes fontes de lipídios testadas na criação de larvas de Jundiá (Rhamdia quelen), Pisces, Pimelodidae. Ciência Rural, v.31, p.129-133, 2001.

Received February 27, 2003

Accepted August 26, 2003 